\title{
Scaling restoration to achieve quantitative enhancement of loon, seaduck, and other seabird populations
}

\author{
Molly B. Sperduto ${ }^{1, *}$, Sean P. Powers ${ }^{2}$, Michael Donlan ${ }^{3}$ \\ ${ }^{1}$ United States Fish and Wildlife Service, 70 Commercial Street, Suite 300, Concord, New Hampshire 03301, USA \\ ${ }^{2}$ Department of Marine Sciences, University of South Alabama and Dauphin Island Sea Lab, 101 Bienville Blvd., \\ Dauphin Island, Alabama 36528, USA \\ ${ }^{3}$ Industrial Economics, 2067 Massachusetts Avenue, Cambridge, Massachusetts 02140, USA
}

\begin{abstract}
The 1996 'North Cape' oil spill along the Rhode Island coast led to the deaths of at least 2292 birds, resulting in an estimated 6275 bird-years lost (adjusted by expected longevity and productivity). We synthesize information on bird population dynamics to develop an appropriate restoration strategy. Marine birds (seaducks, loons, grebes) with natural recovery periods estimated to exceed $1 \mathrm{yr}$ accounted for $87 \%$ of the total bird-years lost. Marine birds (gulls, cormorants, alcids, gannets) with recovery estimated to be less than a year accounted for $10 \%$ of injuries. Common loons Gavia immer and common eiders Somateria mollissima were selected as targets for restoration because of regional concern over their population status and the magnitude of lost bird-years. Three restoration options were evaluated for loons: nest site protection; nest site enhancement; and public education/outreach. Nest site enhancement opportunities were limited and benefits from public education/outreach efforts were uncertain. Nest site protection was preferred for both loons and eiders because nest site availability and/or quality currently limit(s) productivity. This option assumes that preventing future productivity loss compensates for productivity loss that resulted from the 'North Cape' oil spill. This assumption is supported by regional productivity estimates for the 2 target species, is consistent with scientific literature, and represents the consensus of expert opinions. Based on a series of scaling calculations, protection of 25 nest sites for a $100 \mathrm{yr}$ period is expected to balance the loss of 2920 loon-years. Protection of 315 eider nest sites over a 100 yr period would replace 2605 bird-years lost (remaining marine bird injury). Calculations adjust future production credit through economic discounting of $3 \% \mathrm{yr}^{-1}$. Our analysis provides a means of quantifying the level of breeding habitat protection required to restore injured populations of marine birds.
\end{abstract}

KEY WORDS: Restoration - Habitat protection - Marine birds · Oil spill · Seabird · Habitat equivalency analysis

\section{INTRODUCTION}

Direct and indirect population losses resulting from pollution (Burger \& Gochfeld 2001), habitat destruction or degradation (Boersma et al. 2001), and overexploitation of prey resources by humans (Montevecchi 2001) are common in many bird species that rely on coastal habitats. These and other threats result in a need for effective mechanisms to conserve and restore coastal bird populations. Although a relatively wide range of potential restoration options exists for many injured and declining marine resources, practical constraints limit their suitability for marine birds. For example, unlike restoration opportunities for many species of marine fishes and invertebrates, it is not practical, nor in many cases possible, to replace dead, injured or missing birds directly through captive breeding programs. Although the creation of some types of new 
habitat is possible and may be an effective mechanism for enhancing fish and invertebrate populations (Peterson et al. 2003a, in this Theme Section), creating shoreline for coastal bird species would typically be enormously expensive. In contrast to many marine fish and invertebrate species, however, considerable efforts to conserve bird populations have been conducted for decades by government and private entities. Such initiatives can provide 'blueprints' for practical, costeffective restorations of injured bird populations.

Significant seabird mortalities are common after oil spills in coastal areas because marine birds frequently occur in large aggregations, rafting, floating, and feeding on the water surface (e.g. Piatt \& Lensink 1989, Burger 1997, Irons et al. 2000, Peterson 2001). Oilinduced matting of feathers causes loss of insulation and water repellency functions, leading to hypothermia, starvation, or drowning (Burger \& Gochfeld 2001). Ingestion of oil, primarily through preening, can result in further mortality of birds (Coon \& Dieter 1981, Burger \& Gochfeld 2001). Chronic effects from exposure to hydrocarbons remaining after the spill may be expressed as lowered breeding success (Grau et al. 1977, Fry et al. 1986, Hoffman 1990), reduced fledgling growth and survival (Trivelpiece et al. 1984, Hoffman 1990), developmental and behavioral abnormalities (Burger \& Gochfeld 2001) and reduced adult survival for several years (Esler et al. 2000). Indirect negative effects of oil spills on marine birds may occur from habitat degradation or reduction in prey resources (Agler et al. 1999, Peterson 2001).

Here we use information about population-limiting factors in loons, seaducks and other marine birds to develop appropriate restoration methods for injured bird resources. First we review the methodology used to quantify injury to marine birds resulting from the 1996 'North Cape' oil spill. Of particular significance to marine birds was the timing of the 'North Cape' oil spill: the January release of a large quantity of home heating oil along the Rhode Island coastline coincided with the concentration of many wintering waterbird species in nearshore areas. We evaluate 3 restoration options intended to enhance populations of marine birds to offset losses: protection of habitat from future development, nest-site enhancement, and public outreach/ education designed to decrease human-related mortality. In addition, we present the methodology used to quantitatively evaluate the favored restoration option.

\section{MATERIALS AND METHODS}

Injury quantification. The basis for quantifying the total injury of seabirds, salt pond birds, and non-water birds is the recovery of dead or dying birds, application of a multiplier to account for the proportion of dead birds not recovered, and calculation of production foregone by these dead birds and their progeny. The number of marine birds (salt pond birds and seabirds) found dead during and after a spill typically underestimates total mortality resulting from an oil spill (Hlady \& Burger 1993). Therefore a multiplier is appropriately used to account for the birds that sink, drift out to sea, or are scavenged. Our search of the literature found that the maximum multiplier used in poorly documented spills was 10 (Burger 1993). The mean multiplier from a review of 45 oil spills (Burger 1993) was 4 to 5. A multiplier of 6 was applied to marine and saltpond birds for the 'North Cape' spill because currents and wind speeds were sufficiently strong to disburse oil over a great area and to transport large numbers of birds offshore. A multiplier was not used for non-water birds because recovery rates for carcasses of these species are generally high. Only 12 non-water birds were found dead.

To estimate the interim loss of birds resulting from the spill (the loss from the time of the injury until injured resources recover), the number of each bird species killed was multiplied by its estimated recovery period (defined as the time necessary for the population to reach pre-spill, baseline levels), resulting in bird-years lost. To estimate recovery periods, we reviewed data on production of fledglings, survival rates, maximum lifespan, and current population abundances for each species (Table 1), as well as the numbers of each species or taxon that suffered losses from the spill (Table 2). Based on this information, we divided the injured species (taxa) into 2 groups, corresponding to those whose recovery would likely be complete during the first breeding season vs. those whose recovery would require a longer time period. For species in this first group, data on current population levels, survival rates and productivity support a conclusion that natural compensatory mechanisms would restore population levels during the first breeding season. Species (taxa) with recovery times estimated to be greater than $1 \mathrm{yr}$, generally breed at older ages, have lower reproductive success, and, in this instance, suffered high spill-related mortality. Recovery periods in this group were estimated to equal their expected lifetimes in the absence of the spill. This simplification was used as a proxy for return to baseline levels, although clearly compensatory mechanisms could result in 'replacement' of these birds sooner. Alternatively, if populations are in decline, recovery could take longer.

The calculation of recovery time for species judged to require more than the first breeding season required information on age structure of the bird populations killed by the spill, and on natural mortality rates. Due 
Table 1. Biological parameters for marine birds whose recovery is estimated to require more than 1 breeding season

\begin{tabular}{|c|c|c|c|c|c|c|}
\hline Species & $\begin{array}{l}\text { Fledgling } \\
(1 \text { st year) } \\
\text { survival } \\
\text { rate }\end{array}$ & $\begin{array}{l}\text { Post- } \\
\text { fledgling } \\
\text { survival } \\
\text { rate }\end{array}$ & $\begin{array}{l}\text { Max } \\
\text { age } \\
\text { (yr) }\end{array}$ & $\begin{array}{l}\text { Breeding } \\
\text { age } \\
\text { (yr) }\end{array}$ & $\begin{array}{l}\text { Young/ } \\
\text { individual }\end{array}$ & Source \\
\hline $\begin{array}{l}\text { Scoters (black Melanitta nigra } \\
\text { and surf } M . \text { perspicillata) }\end{array}$ & 0.40 & 0.75 & 15 & 2 & 1.3 & $\begin{array}{l}\text { Johnsgard (1975), } \\
\text { Bordage \& Savard (1995) }\end{array}$ \\
\hline Red-breasted merganser & & & & & & \\
\hline Mergus serrator & 0.15 & 0.60 & 15 & 2 & 1.3 & Johnsgard (1975) \\
\hline Goldeneye Bucephala clangula & 0.27 & 0.64 & 15 & 3 & 0.9 & Eadie et al. (1995) \\
\hline Bufflehead Bucephala albeola & 0.39 & 0.59 & 15 & 2 & 1.1 & Johnsgard (1975), Gauthier (1993) \\
\hline Common eider Somateria mollissima & 0.20 & 0.68 & 21 & 2 to 4 & 0.64 & $\begin{array}{l}\text { Johnsgard (1975), Bellrose (1976), } \\
\text { Blumton et al. (1988), Goudie et al. } \\
\text { (2000), B. Allen pers. comm. }\end{array}$ \\
\hline $\begin{array}{l}\text { Grebes (horned Podiceps auritus } \\
\text { and red-necked P. grisegena) }\end{array}$ & 0.60 & 0.62 & 24 & 2 & 0.91 & $\begin{array}{l}\text { Fjeldsa (1973), Clapp et al. (1982), } \\
\text { Johnsgard (1987), } \\
\text { French et al. (1996), } \\
\text { G. Neuchterlein pers. comm. }\end{array}$ \\
\hline $\begin{array}{l}\text { Loons (common Gavia immer } \\
\text { and red-throated G. stellata) }\end{array}$ & 0.76 & 0.88 & 24 & 5 & 0.27 & $\begin{array}{l}\text { Belant \& Anderson (1991), } \\
\text { Croskery (1991), Evers (1993, 2001), } \\
\text { French et al. (1996), McIntyre \& } \\
\text { Barr (1997), Taylor \& Vogel (1998) }\end{array}$ \\
\hline
\end{tabular}

to the inability to age bird carcasses found during the recovery effort, we used the simplifying assumption that birds killed by the spill were of average age for their respective populations. To estimate average age, we first determined age-specific survival rates and the maximum attainable age for each taxon through review of available literature (Table 1). To the extent possible, several literature estimates were averaged for each parameter. For all taxa, a fledgling survival rate was applied for the first year and a constant rate of annual survival applied to each subsequent year (postfledgling to adult) up to the maximum attainable age (Table 1). The number of age classes was dictated by the maximum attainable age, whereas the age distribution was computed by applying the annual survival rates. Average age was then determined by calculating a weighted average age.

Using the weighted average age for those taxa whose recovery was estimated to exceed 1 breeding season, the number of additional years that an average-aged bird would have been expected to live in the absence of the spill can be calculated. This time period is estimated by simple demography. For example, the average-aged scoter of $3.8 \mathrm{yr}$ killed by the spill could have lived 11 additional years, given a maximum age of 15 (Table 1). The probability of surviving 1 more year in the absence of the spill is 0.75 , the annual survival rate for post fledgling scoters (Table 1). The probability of surviving both a first and second year is the survival rate raised to the second power, and so on. Summing the probabilities of survival for each remain- ing age class beyond the calculated average age gives the number of additional years an average-aged bird would be expected to survive. For scoters this equation is $(0.75)^{1}(1 \mathrm{yr})+(0.75)^{2}(1 \mathrm{yr})+(0.75)^{3}(1 \mathrm{yr}) \ldots+(0.75)^{11}$ $(1 \mathrm{yr})=2.87 \mathrm{yr}$. Thus, an average-aged scoter would likely live 2.87 additional years if the spill had not occurred. Total bird-years lost for birds that died as a result of the spill was then estimated by multiplying the additional years a bird would have lived in the absence of the spill by the number of individuals killed by the spill.

The use of a 'bird-years' metric to calculate the scale of injury and restoration offers several advantages. A primary advantage to the 'bird-years' approach is that it corrects for the fact that some bird species have a much longer lifespan than others. This often is an important consideration when injuries to several species are 'combined' into a single habitat project that restores these injuries through productivity increases to a smaller number of bird species. In those circumstances, if scaling is done using 'birds lost' instead of 'bird-years', some long-lived birds killed by the spill will be inappropriately 'replaced' by short-lived birds or vice-versa. For injury quantification purposes, this method involves estimation of the number of years injured birds would have lived if the spill had not occurred. From a restoration perspective, credit reflects the number of years that birds produced by the proposed restoration are expected to live. Another potential benefit of the bird-years approach is that it can help correct for disparities related to the age distri- 
Table 2. Injury quantification for birds killed by the 'North Cape' oil spill

\begin{tabular}{|c|c|c|c|c|c|c|c|}
\hline & & $\begin{array}{l}\text { Number } \\
\text { recovered }\end{array}$ & $\begin{array}{c}\text { Total } \\
\text { kill }\end{array}$ & $\begin{array}{l}\text { Discounted life } \\
\text { expectancy (yr) }\end{array}$ & $\begin{array}{c}\text { Direct } \\
\text { mortality } \\
\text { (bird-years) }\end{array}$ & $\begin{array}{l}\text { Fledgling } \\
\text { production lost } \\
\text { (bird-years) }\end{array}$ & $\begin{array}{l}\text { Total bird- } \\
\text { years lost }\end{array}$ \\
\hline \multicolumn{8}{|c|}{ Marine birds - long term impact likely } \\
\hline Common loon & Gavia immer & 67 & 402 & 5.46 & 2196 & 639 & 2835 \\
\hline Common eider & Somateria mollissima & 59 & 354 & 1.93 & 685 & 168 & 853 \\
\hline Grebes (horned, red-necked) & $\begin{array}{l}\text { Podiceps auritus, } \\
\text { P. grisegena }\end{array}$ & 38 & 228 & 1.51 & 345 & 360 & 705 \\
\hline Goldeneye & Bucephala clangula & 32 & 192 & 1.64 & 314 & 94 & 408 \\
\hline Red-breasted merganser & Mergus serrator & 34 & 204 & 1.39 & 284 & 53 & 337 \\
\hline Bufflehead & Bucephala albeola & 11 & 66 & 1.34 & 88 & 37 & 125 \\
\hline Scoters (black, surf) & $\begin{array}{l}\text { Melanitta nigra, } \\
\text { M. perspicillata }\end{array}$ & 3 & 18 & 2.60 & 47 & 64 & 111 \\
\hline Red-throated loon & Gavia stellata & 2 & 12 & 5.46 & 66 & 19 & 85 \\
\hline Subtotal & & 246 & 1476 & & 4025 & 1434 & 5459 \\
\hline \multicolumn{8}{|c|}{ Marine birds - long term impact unlikely } \\
\hline $\begin{array}{l}\text { Gulls (great black-backed, } \\
\text { herring) }\end{array}$ & $\begin{array}{l}\text { Larus marinus, } \\
\text { L. argentatus }\end{array}$ & 74 & 444 & 1.00 & 444 & 0 & 444 \\
\hline Cormorant & Phalacocrax auritus & 16 & 96 & 1.00 & 96 & 0 & 96 \\
\hline Murre & Uria aalge & 5 & 30 & 1.00 & 30 & 0 & 30 \\
\hline Gannet & Morus bassanus & 3 & 18 & 1.00 & 18 & 0 & 18 \\
\hline Razorbill & Alca torda & 2 & 12 & 1.00 & 12 & 0 & 12 \\
\hline Dovekie & Alle alle & 1 & 6 & 1.00 & 6 & 0 & 6 \\
\hline Subtotal & & 101 & 606 & & 606 & & 606 \\
\hline \multicolumn{8}{|c|}{ Salt-pond birds-long term impact unlikely } \\
\hline Great blue heron & Ardea herodias & 6 & 36 & 1.00 & 36 & 0 & 36 \\
\hline Canada goose & Branta canadensis & 6 & 36 & 1.00 & 36 & 0 & 36 \\
\hline Black duck & Anas rubripes & 5 & 30 & 1.00 & 30 & 0 & 30 \\
\hline Scaup & Aythya affinis & 4 & 24 & 1.00 & 24 & 0 & 24 \\
\hline Mute swan & Cygnus olor & 4 & 24 & 1.00 & 24 & 0 & 24 \\
\hline Mallard & Anas platyrhyncos & 3 & 18 & 1.00 & 18 & 0 & 18 \\
\hline Pintail & Anas acuta & 2 & 12 & 1.00 & 12 & 0 & 12 \\
\hline Ruddy duck & Oxyura jamaicensis & 2 & 12 & 1.00 & 12 & 0 & 12 \\
\hline Coot & Fulica americana & 1 & 6 & 1.00 & 6 & 0 & 6 \\
\hline Subtotal & & 33 & 198 & & 198 & & 198 \\
\hline \multicolumn{2}{|c|}{ Non-water birds - long term impacts unlikely } & 12 & 12 & 1.00 & 12 & 0 & 12 \\
\hline \multicolumn{2}{|l|}{ Total } & 392 & 2292 & & 4841 & 1434 & 6275 \\
\hline
\end{tabular}

bution of injured and restored birds. In some cases, environmental insults may kill birds that are near the end of their natural lives while restoration projects replace them with birds that have their entire lifespans ahead of them. In most cases there are no field data available concerning the ages of birds killed by the perturbations.

For species (taxa) whose recoveries were estimated to exceed 1 breeding season, the loss in bird-years expected from first-generation fledglings that would have been but were not produced by breeding adults killed by the 'North Cape' oil spill was added to the mortality injury. For this computation, we first estimated the percentage of birds killed by the 'North Cape' spill that would have produced young in the absence of the spill. For grebes, mergansers, goldeneye, buffleheads, scoters and eiders (this group constitutes all of the taxa whose recoveries were estimated to exceed 1 breeding season, with the exception of loons), we assumed that all birds of breeding age would have maintained breeding territories and would have attempted to produce young had the spill not killed them. This assumption is supported by information obtained from Eadie et al. (1995), which indicates that over $90 \%$ of breeding-age common goldeneyes breed in a given year. For these species (taxa), we calculated the proportion of the population in each age class using the survival rates. We then summed over all age classes equal to or greater than the breeding age identified in the literature (Table 1) to determine the proportion of breeding birds killed by the spill. Finally, to estimate the bird-years lost by fledglings-never-hatched for grebes, mergansers, goldeneyes, buffleheads, scoters, and eiders, the number of fledglings produced per breeding individual per season (Table 1) was multiplied by the average life span of a fledgling. These calculations were repeated for each breeding season that a 
killed bird would have been expected to produce fledglings in the absence of the spill. The average life span of fledglings was calculated using the age-specific survival probabilities previously described. Using scoters as an example, approximately 1.58 bird-years are expected from each fledgling over the course of its lifetime with a fledgling survival of 0.4 , an adult survival rate of 0.75 , and a maximum life span of 15 yr. For scoters, the total fledgling production foregone per year was 27.7 birdyears lost based on $75 \%$ of the 18 individuals killed by the spill of breeding age and 1.3 fledglings produced per breeder and a fledgling life expectancy of 1.58 birdyears (i.e. 18 scoters $\times 0.75 \times 1.3$ fledglings per scoter $\times$ 1.58 bird-years lost per fledgling). Next, we used the estimate of how long an average-aged bird would have lived had the spill not occurred to compute the number of breeding seasons foregone as a result of the spill. For scoter this value is $2.87 \mathrm{yr}$, and so we assumed that an average-aged bird would have been expected to produce fledglings for 3 breeding seasons following the spill. Each season's fledgling production foregone by loss of the birds killed by the spill was summed to calculate the total fledgling production foregone as a portion of the injury.

For loons, computing loss of fledglings requires a more complex conceptualization of loon nesting behavior. Based on information from a 22 yr database from New Hampshire established by the Loon Preservation Committee (Taylor \& Vogel 2000), 66\% of the loons killed by the spill were estimated to be 'breeding' loons, while $20 \%$ comprised non-breeder adults and the remaining $14 \%$ represented the young-of-the-year cohort. If an established territory is vacant due to death or divorce of the breeding adults, non-breeding adults regularly and quickly fill that void (Piper et al. 2000; Evers 2001). Decreases in fledgling production as a result of 'breeding' loon deaths may be partially offset by the otherwise non-breeding adults because pre-spill loon populations consisted of a number of reproductively competent birds that did not breed (i.e. up to $20 \%$ ). However, due to decreased experience and fitness of these otherwise non-breeding adults, fewer fledglings are produced by the replacement loons in the first few years (for birds: Owen \& Black 1989, Wooller et al. 1989, for loons: D. Evers pers. com.). To account for the role of these non-breeding loons in post-spill recovery, we estimated that their fledgling production would be reduced for $2 \mathrm{yr}$. The production losses expected for the remaining $4 \mathrm{yr}$ in which a breeding adult killed by the spill would have been expected to produce young were not included, since otherwise non-breeding adults in the population were expected to have filled the available territories. It is important to note that spills especially destructive to loon populations could effectively eliminate the 'non-breeding' as well as the 'breeding' cohort, thereby preventing immediate occupancy of vacant breeding territories, resulting in little or no off-setting production of fledglings.

Restoration scaling. Restoration focused on marine birds adversely affected by the spill, and whose recovery period was estimated to exceed 1 breeding season (loons, grebes, mergansers, goldeneyes, buffleheads, scoters, and eiders). The magnitude of injury to loons required that restoration include specific actions to off-set the loon injury. The cost and the logistic difficulty of developing and implementing multiple, small restoration projects for each of the other injured bird species led us to seek a single project that would restore the remaining injured species. The focus of this second component was restoration of sea duck populations with particular attention to eiders.

Life history data for common loons Gavia immer and common eiders Somateria mollissima were used to scale appropriate restoration (Table 3). Loons display strong territorial behaviors during nest occupation, which occurs along shorelines of freshwater lakes (Piper et al. 2000). Eiders breed primarily along shorelines of coastal islands, where they do not generally exhibit territorial behavior, but show some degree of cooperation among female breeders during nesting (Kilpi \& Lindstrom 1997). Both taxa are monogamous with loons forming durable pair bonds (i.e. multiple seasons) and eiders pairing briefly for breeding. Loons and eiders are long-lived, with deferred reproductive maturity and low annual productivity of fledglings (see Table 3).

Three restoration options were evaluated to offset losses of loons resulting from the 'North Cape' oil spill: habitat protection, nest-site enhancement, and public outreach/education. The first 2 options increase loon populations through enhancement of fledgling production at nest sites, whereas public outreach/education seeks to mitigate loss of birds through prevention of human-related mortality. Specifically, habitat protection through the purchase of land or development rights in areas of bird nesting is expected to restore bird populations by preventing future decline in fledgling production resulting from land development and habitat degradation. Nest-site enhancement involves the installation of artificial nest sites (Piper et al. 2002) on lakes that have poor nesting habitat, fluctuating water levels, or histories of low reproductive output of loons. The education and public outreach option seeks to decrease adult loon deaths from human activity, such as motorboat trauma, lead sinker poisoning, or fishing line entanglement (Caron \& Robinson 1994, Carney \& Sydeman 1999). Public outreach also could reduce human interference with breeding loons by boaters, swimmers, and other recreators, thus increasing fledgling production per nest site. 
Table 3. Values for biological, economic and project parameters used in the restoration scaling calculations for common loons Gavia immer, red-throated loons G. stellata and common eiders Somateria mollissima

\begin{tabular}{|c|c|c|}
\hline Biological parameter & Loon restoration & Eider restoration \\
\hline Productivity gain at protected area & 0.5 fledglings nest site ${ }^{-1} \mathrm{yr}^{-1}$ & 0.4 fledglings nest site ${ }^{-1} \mathrm{yr}^{-1}$ \\
\hline Productivity of offspring & 0.54 fledglings territorial pair-1 $\mathrm{yr}^{-1}$ & 0.4 fledglings eider pair $^{-1} \mathrm{yr}^{-1}$ \\
\hline 1st year (Fledgling) survival rate & 0.76 & 0.20 \\
\hline Adult survival rate & 0.88 & 0.68 \\
\hline \multicolumn{3}{|l|}{ Average life expectancy of a newly } \\
\hline hatched bird (discounted) & $4.95 \mathrm{yr}$ & $0.57 \mathrm{yr}$ \\
\hline Breeding age & $5 \mathrm{yr}$ & $2 \mathrm{yr}$ \\
\hline Maximum age & $24 \mathrm{yr}$ & $15 \mathrm{yr}$ \\
\hline \multicolumn{3}{|l|}{ Proportion of adult birds } \\
\hline that maintain territories & 0.80 & 1.0 \\
\hline Discount rate & $0.03 \mathrm{yr}^{-1}$ & $0.03 \mathrm{yr}^{-1}$ \\
\hline Project life-time & $100 \mathrm{yr}$ & $100 \mathrm{yr}$ \\
\hline
\end{tabular}

Scaling the proposed restoration options to compensate for lost bird-years requires quantifying the degree to which bird populations are enhanced by each restoration option. Enhancement was estimated through a comprehensive review of available (both published and unpublished) data sets that (1) contrast or estimate productivity differences between developed and undeveloped breeding areas (habitat protection option), (2) evaluate fledgling production at artificial nest sites (nest-site enhancement option), and/or (3) report the number of deaths or other impacts from human-related disturbance and quantify success in past efforts to reduce such impacts (education/public outreach). Once the degree of benefit was estimated, the next step in the scaling computations involved determining the appropriate size of the restoration based on the benefit, the life expectancy of the restoration project and life-history parameters for each species of birds.

For the habitat protection option, we estimated the productivity gains for a single protected nest to determine the total number of protected nests necessary to compensate for the bird injury. Offspring hatched at each protected nest site (first-generation productivity) as well as offspring later produced by these birds (second-generation productivity) were included in the calculations of habitat protection benefits. Firstgeneration production of each nest site (expressed in bird-years) was calculated by multiplying the productivity gain per protected nest site (the difference in fledgling production between a protected and an unprotected nest, PG) by the average life expectancy $(L)$ of a newly hatched bird. The productivity gain was assumed to recur each year $(t)$ over a 100 yr project life time (PL). Although the benefits of the project are theoretically indefinite since the land cannot be developed, application of economic discounting at a $3 \%$ annual rate (see 'Discounting' section below) means that birds produced near the end of the $100 \mathrm{yr}$ lifetime contribute little to the total productivity gain. Thus, the equation to calculate augmented production of fledglings associated with the first-generation of offspring attributed to a protected nest site is:

$$
\sum_{t=1}^{\mathrm{PL}}(\mathrm{PG} \times L)
$$

The first-generation offspring resulting from a protected nest site begin producing their own offspring (second-generation offspring) from their speciesspecific breeding age (BA) until they die at their species-specific maximum age (MA). To calculate the restoration benefit of expected bird-years achieved by these second-generation offspring, we used the equation

$$
\sum_{t=\mathrm{BA}}^{\mathrm{MA}}\left(\mathrm{PG} \times \mathrm{FS} \times \mathrm{AS}^{t-1} \times \mathrm{pA} \times \frac{\mathrm{PLO}}{2} \times L\right)
$$

where FS is the fledgling survival rate, AS is the annual adult survival rate, $\mathrm{pA}$ is the proportion of adults that breed, PLO/2 is the annual productivity (based on average sites across the population) of bird offspring (per individual) and the other terms are the same as in Eq (1). Inclusion of the FS and AS variables to PG in Eq. (2) accounts for the expected mortality rates of the first-generation birds (i.e. the product of the first 3 terms in the equation gives the number of first-generation offspring per protected nest that could breed). Application of the pA term accounts for the fact that not all adults breed, generally because of behavioral and environmental constraints (i.e. the product of the first 4 terms in the equation gives the number of birds per protected nest that actually breed). Multiplication of the actual number of breeders by PLO/2 gives the number of second-generation offspring per protected nest produced in a single year. The PLO term is divided by 2 to account for the fact that the productivity parameter is a per-pair estimate, rather than a perindividual estimate. The number of second-generation offspring per protected nest is then multiplied by $L$ to 
estimate the number of bird-years expected from these second-generation offspring. Credit for fledglings produced beyond the second generation was not included in the restoration scaling nor was it included in the damage assessment. Given the potential role of density-independent factors that may affect populations over long time spans, extending impacts or benefits beyond the second generation was viewed as too speculative. The sum of the second-generation bird-years produced by the offspring of all of the first-generation birds is calculated as:

$\sum_{t=1}^{\text {PL }} \begin{aligned} & \text { Second-generation bird-years produced } \\ & \text { by Year } t \text { first-generation birds }\end{aligned}$

Once the productivity gain in bird-years per protected nest site over the 100 yr project (Eq. 1 + Eq. 3) was estimated, we then determined the number of nests required to compensate for the bird injury.

In addition to enhanced production of fledglings, protection of nest sites may result in higher survivorship of adult birds through prevention of recreation/ development-related mortality at nest sites. To estimate this benefit, we reviewed 10 yr (1989 to 1998) of monitoring data collected by the Loon Preservation Committee for New Hampshire lakes. The data set documents mortality of loons by region within the state and includes cause of death determinations made by veterinarians at Tufts University. The data set was examined by region to determine the differences between developed and undeveloped areas. To calculate the adult survival credit for habitat protection, the numbers of loon deaths due to boat trauma, fishing gear, plastics, and lead sinkers were determined for developed and undeveloped areas. The total number of deaths due to these human-induced traumas was then divided by the regional bird population estimate to determine the proportion of birds likely to be killed. The proportion for undeveloped lakes was then subtracted from that for developed lakes to calculate the survival credit for protecting adults. To determine the number of adults that are 'saved' through reducing human-induced mortality, the estimated bird population in the protected area (the area purchased as part of the restoration project) was multiplied by the survival credit. The resulting number of birds saved was then substituted for PG in Eq. (1) to determine the number of bird-years credited to this component of the restoration option.

Discounting. To account for the time-lag between the injury and the start of restoration as well as the time required (several decades) for the restoration project to balance the original injury, damages and restoration credits were adjusted by an annual discounting rate of $3 \%$. This rate, commonly used in natural resource damage assessments (NOAA 1999), approximates the additional amount of a good or service required by society as compensation for delaying provision of the good or service by an additional year. In our computation, the injury was expressed in 1996 bird-years (the year of the oil spill) and the total compensatory restoration goal (injury adjusted by $3 \%$ annually) and restoration scaling calculations were expressed in 2000 bird-years (the start of the restoration project). In calculating the injury, the annual survival rate (both fledgling and adult rates) was discounted by $3 \%$ to estimate the 1996 value of birdyears lost in the future. For example, annual survival rate for post-fledgling (adult) scoters is 0.75 (Table 1). After 1 yr (i.e. 1997) this value decreases to 0.73 $\left(0.75 / 1.03^{1}\right)$ and after $2 \mathrm{yr}$ the value decreases to 0.71 $\left(0.75 / 1.03^{2}\right)$. In calculating the restoration credit, the annual production credit for each nest site (Eq. 1) was discounted to the year that the restoration project starts. Specifically, Eq. (1) is multiplied by the term $(1+\mathrm{DR})^{-t}$, where $t$ is equal to the year after the start of the restoration project (1 to 100) and DR is the annual discount rate (0.03). Because fledglings hatched in that year will live for multiple years (predicted by their average life expectancy), the future years of fledgling production are also discounted (the DL term in Eq. 4). This latter discounting is achieved through discounting the annual survival rate of fledglings produced during that year (as in the injury calculations). Applying the above discounting to Eq. (1), the equation calculating the restoration benefit associated with the first-generation of offspring attributable to a protected nest site (measured in Year 2000 birdyears) is:

$$
\sum_{t=1}^{\mathrm{PL}}(\mathrm{PG} \times \mathrm{DL}) \times(1+\mathrm{DR})^{-t}
$$

where DL is the life expectancy calculated using the discounted survival rates and all other parameters are the same as defined under Eq. (1).

The production of fledglings by birds hatched at a protected nest site (second-generation birds) is discounted back to the year that their parents were hatched $(t-\mathrm{BA})$. Because these second-generation fledglings live beyond the year when they are hatched, their future production is adjusted through discounting their future annual survival rates (as in the injury calculations). Applying the above discounting to Eq. (2), the equation calculating the restoration benefit associated with the fledglings produced by the firstgeneration birds is:

$$
\sum_{t=\mathrm{BA}}^{\mathrm{MA}}\left[\mathrm{PG} \times \mathrm{FS} \times \mathrm{AS}^{t-1} \times \mathrm{pA} \times \frac{\mathrm{PLO}}{2} \times \mathrm{DL} \times(1+\mathrm{DR})^{-(t-\mathrm{BA})}\right](5)
$$


Finally, Eq. (3), which sums bird-years produced by the offspring of all of the first-generation birds, is expressed in terms of Year 2000 bird-years by application of a discounting term:

$\sum_{t=1}^{\text {PL }} \begin{aligned} & \text { Second-generation bird-years produced } \\ & \text { by Year } t \text { first-generation birds } \times(1+\mathrm{DR})^{-t}\end{aligned}$

\section{RESULTS}

\section{Injury quantification}

During and after the 'North Cape' oil spill, 405 oiled birds (of which 392 eventually died) were recovered. After application of the multiplier to account for dead but unrecovered water birds, total direct mortality of birds was estimated to be 2292 individuals. Marine birds (sea ducks, loons, grebes, alcids, gannets, gulls and cormorants) comprised the majority (2082), with salt pond birds (ducks, geese, swans and herons) and non-water birds (owls and doves) contributing much less (Table 2). For marine birds, gulls (444) were killed in greatest numbers, followed by common loons (402), eiders (354), grebes (228), mergansers (204), and goldeneyes (192).

Available data on productivity, age-specific survivorship, and population abundances indicate that nonwater birds, salt pond birds, alcids (murres, doveskies, razorbills) and gannets likely were restored through natural recovery during the first breeding season following the spill. Relatively few individuals of each of these species $(<40)$ were estimated to have been killed, and natural compensatory mechanisms were expected to quickly restore these bird populations to baseline levels. Natural compensatory mechanisms (i.e. decreased competition for resources, increased availability of nest sites) also were expected to allow rapid natural restoration of gulls and cormorants to baseline levels. Although these taxa were killed in larger numbers (444 gulls and 96 cormorants), their populations are known to be increasing in size in this region. In contrast, recovery times for sea ducks (mergansers, goldeneye, bufflehead, scoters and eiders), loons (common and red-throated) and grebes (Table 2) were determined to require more than 1 breeding season. Although the regional breeding populations of these species may be adequate to allow natural recovery, the relatively late age of first breeding and low reproductive success (Table 1) coupled with the large numbers of these birds killed by the spill contributed to a judgement that natural recovery would extend beyond 1 breeding season.

The total interim loss of bird production resulting from the 'North Cape' oil spill (Table 2) was estimated as 6275 bird-years. Marine birds whose recovery was estimated to extend beyond 1 breeding season accounted for $87 \%$ of this total (5459 bird-years) with marine birds whose recovery was complete during the first post-spill breeding season accounting for $10 \%$ (606 bird-years) and pond and non-water birds accounting for $3 \%$ (198 bird-years). Loss of the first generation of fledglings accounted for $26 \%$ (1434 birdyears) of the total injury to marine birds with recovery periods extending beyond 1 breeding season (5459 bird-years). Losses were greatest for loons (2835 birdyears) and eiders (853 bird-years).

\section{Restoration scaling}

Limited information was available to quantify the expected production gain for loons for the 3 restoration options. Based on data collected by the Loon Preservation Committee from 1993 to 1998 from developed and undeveloped areas, protected nest sites produced 0.4 more fledglings per nest than nest sites in developed areas. However, for our calculations, the magnitude of improved productivity between undeveloped lakes and developed lakes without management was estimated to be 0.5 more fledglings per nest because the Loon Preservation Committee's data were based on a contrast between developed lakes that had management and educational programs and undeveloped lakes. Unfortunately, similar data to assess the productivity gains for the nest site creation and education/public-outreach options were not available. The lack of data to quantitatively evaluate these options led to the rejection of these 2 restoration choices. Furthermore, many areas that provided the best opportunities for nest site enhancement were already being managed for nesting enhancement; consequently, further potential productivity gains were viewed as marginal at best. However, some qualitative assessment of the nest site creation and education/public outreach options can be made based on the scaling calculations for the habitat protection option.

Based on our estimates of the relevant biological parameters (Table 3), each protected breeding pair of loons and associated nest site will generate approximately 128 additional loon-years (measured in Year 2000 loon-years) over a 100 yr project lifetime. Assuming implementation of the restoration project in 2000, the total loon injury (common and red-throated loons) to be restored is 3286 loon-years, the damage calculation for 1996 (2920 loon-years) expressed in 2000 bird-years $\left(2920 \times[1.03]^{4}\right)$. Therefore, approximately 25.5 nests would be required to meet the restoration goal of 3286 loon-years.

Preventing development of currently undeveloped loon breeding habitat would also be expected to result in higher adult survivorship through prevention of 
recreation-/development-related mortality. Based on the data set collected by the Loon Preservation Committee, the habitat protection project designed to enhance fledgling production would 'save' $2.54 \%$ of the adult loon population each year by reducing mortality resulting from the use of lead sinkers. An additional $0.43 \%$ of the population would be saved each year through decreases in loon mortality resulting from boat trauma, fishing gear and plastics. The adult credit for prevention of boat trauma, fishing gear and plastic was calculated for the 100 yr project lifetime using appropriate discounting. The credit for the prevention of mortality related to the use of lead sinkers was calculated for only the first $10 \mathrm{yr}$ of the project life. The adoption of legislation restricting the use or sale of lead sinkers by Maine and New Hampshire (the likely location for habitat protection) and the likely adoption by neighboring states was presumed to result in reduced mortality rates on developed lakes over the next $10 \mathrm{yr}$. Thus the annual benefit is 1.5 adult loons per year for each of the first $10 \mathrm{yr}$ based on the $2.97 \%$ credit and a population size of 50 protected loons (i.e. 25 protected nest site $\times 2$ loons at each site $\times 0.0297$ ). For the remaining $90 \mathrm{yr}$ of the project, the annual benefit is 0.2 loons $\mathrm{yr}^{-1}$ (50 loons $\left.\times 0.0043\right)$. Consistent with the other injury and restoration calculations, the expected number of loon-years 'saved' by protecting an averaged-age adult is 5.4. Discounting the annual benefits by $3 \%$ annually and summing over a project lifetime of $100 \mathrm{yr}$ results in a credit of 93 loon-years. This credit reduces the number of loon-years needed for restoration through production of fledglings from 3286 to 3193 loon-years and reduces the nest requirements from 25.5 to 25 .

The remainder of the marine bird injury was 2933 bird-years, measured in Year 2000 bird-years. Experiences with human-induced disturbance on islands suggested that development would likely eliminate nesting opportunities for eiders on most islands. Consequently, protection and management of eider nesting islands in Maine could potentially result in improved production to 0.4 fledglings eider pair ${ }^{-1} \mathrm{yr}^{-1}$ (B. Allen pers. comm.). Using this information for eiders and using eiders as the target group for restoring the remainder of the marine bird injury, each protected nest for eiders would be expected to produce an additional 9.3 bird-years (measured in Year 2000 eider-years). Thus, 315 nest sites would need to be protected to restore the remainder of the marine bird injury.

\section{DISCUSSION}

The accuracy of our analyses depends on the assumptions used in both the injury quantification and the restoration scaling. Assumptions are often needed because of the lack of area-specific data, large uncertainty in relevant biological parameters and/or the lack of clear consensus in the literature on key issues (Peterson et al. 2003a). Injury estimates and restoration scaling are highly sensitive to life history data for individual species. Therefore we encourage future users of this method to rely upon the most recent literature to help minimize uncertainty.

The calculated injury does not include longer-term, chronic effects of the spill because our calculations of bird injury resulting from the 'North Cape' oil spill were derived from estimates of acute mortality. Therefore, our calculation represents a conservative estimate of the injury. Decreases in adult or fledgling fitness resulting from direct (exposure to residual hydrocarbon) and indirect effects (oil spill impacts on prey populations) have the potential to adversely impact birds for years after an oil spill (Burger \& Gochfeld 2001, Peterson 2001, Golet et al. 2002). Unfortunately, few empirical data are available to quantify this effect. The most important assumptions regarding restoration are ones that involve identification of the factor(s) that currently limit the target population(s). Once the population bottleneck is identified, restoring the injury involves identifying and scaling the most effective mechanism to overcome this limitation. In our restoration strategy, the primary assumption was that nest-site availability and/or quality limits production of new individuals: an assumption that is supported by regional data sets and is consistent with a larger body of literature. Clutch size and fledgling success have been shown to increase with increasing habitat quality for both common loon and common eider (e.g. Kilpi \& Lindstrom 1997, Gingras \& Paszkowski 1999).

The most reliable mechanism to restore injured loon and eider populations, the target groups for our restoration projects, was judged to be the prevention of future losses in fledgling production of wild populations resulting from expected decreases in the quantity and quality of nesting sites due to development. For loons, purchasing sufficient land and/or land development rights to protect 25 nest sites along shorelines of freshwater lakes with existing loon populations would be expected to compensate for the lost loon productivity resulting from the 'North Cape' oil spill. Similarly, the purchase of sufficient land to protect 315 eider nesting sites would be expected to compensate for the loss of eiders plus all other injured marine birds whose recovery period following the 'North Cape' oil spill was likely to exceed 1 breeding season.

In order for the restoration strategy adopted to be successful, the development pressure must be real: purchase of non-threatened sites would have no impact on productivity of the target species. Caron \& 
Robinson (1994) found that modest levels of human activity (increased recreational use of largely undeveloped lakes in Canada) did not result in decreased fledgling production but suggested that higher levels of human activity or shoreline development could. The closest breeding grounds for loons injured in the 'North Cape' oil spill, which occurred in Rhode Island, are in New Hampshire and Maine where many of these areas are indeed under growing development pressure. Concerns about the stability of loon populations in the northeastern US reflect the large number of specific threats to breeding and wintering populations. Currently, Vermont lists the common loon as an endangered species. In New Hampshire loons are listed as threatened, and in Massachusetts, Connecticut and New York they are listed as species of special concern. Shoreline development on loon breeding lakes is a conservation issue because it eliminates use of historically productive territories and increases human disturbance at nest sites. Similarly, increased development on privately owned islands in Maine, which support substantial numbers of breeding eiders, may dramatically reduce fledgling production of eiders. Purchase and protection of a subset of these islands could meet the requirements necessary for eider restoration by decreasing the adverse effects associated with development on many of them.

The 2 options that were not chosen for the restoration project, nest-site creation and education/public outreach, were judged too uncertain in the degree to which they could produce the large quantity of birdyears required by the restoration plan. This uncertainty was primarily a function of the lack of applicable data sets, particularly for the education/outreach component, and a lack of remaining opportunities (nestsite enhancement) for the expected number of sites needed. The underlying mechanism by which nest-site creation results in additional loon productivity is similar to that of habitat protection, increasing nest-site availability/quality. The specific number of nest site platforms required will depend on the productivity benefit attributable to each platform, as well as platform duration. At the time when the restoration project was planned, there were few empirical data available to quantify the productivity gains of artificial nest sites. However, a recent study by Piper et al. (2002) conducted in several small Wisconsin lakes concluded that floating platforms could increase reproductive success of common loons. When compared to natural nest sites, platforms increased both hatching success $(+69 \%)$ and early fledgling survival $(+32 \%)$. The increased success was attributed to decreased levels of mammalian predation (primarily raccoons). Compared with reference lakes that had a fledgling rate of 0.56 chicks pair ${ }^{-1}$ season $^{-1}$, similar lakes with platforms had fledgling rates of 0.74 pair $^{-1}$. The low durability of the platforms over multiple seasons was considered a serious limitation for the restoration potential of floating platforms. The preferred loon habitat protection project requires protection of 25 nests. The associated productivity benefit ( 0.5 fledglings per nest) and protection duration $(+100 \mathrm{yr})$ is greater than could be achieved by nesting platforms (assuming Piper et al. 2002 results apply to New Hampshire lakes). As a result, the number of platforms needed to meet the restoration goal for loons would be 3 to 4 times the number of nests that must be protected under the habitat protection project. In addition, a long-term management and maintenance plan (Piper et al. 2002) would need to be adopted to insure the necessary project lifetime of the floating platforms. Such considerations will generally apply to restoration options that involve engineered structures instead of allowing natural processes to proceed to enhance populations.

Productivity benefits associated with the education/ public outreach option were judged too uncertain for choice as the restoration option. Although undoubtedly beneficial (e.g. McIntyre 1988, Burger 2003), it is extremely difficult to quantify the benefits of existing programs in the absence of long-term studies. Further complicating this analysis would be quantifying the marginal benefits generated by additional spending on education and outreach above the programs already in place. In areas that do not have existing education/ public-outreach programs or where human activity is known to be a significant source of disturbance (e.g. personal water craft, Burger 2003), closer examination of this restoration option is necessary. For our analysis, any benefit gain would at most be similar to those calculated for the adult credit of breeding ground protection: the expected number of loon-years 'saved' by protecting an averaged-age adult is $5.4 \mathrm{yr}^{-1}$ assuming an adult population of 50 in the area. Discounting the annual benefits by $3 \%$ annually and summing over a project lifetime of $100 \mathrm{yr}$ results in a credit of 93 loonyears. This benefit is substantially smaller than the increases in fledgling production achieved through nest-site protection. Expanding the education/public outreach to a larger area could increase the number of loon-years saved through this restoration option; however, the cost of such a long-term program would probably be higher than the purchase and protection of nest sites.

Offsetting injury to marine birds by prevention of future losses through habitat protection has advantages over any alternative that might involve artificial propagation of replacement birds over a short time period. The injection of a short-term pulse of relatively large numbers of replacement birds could result in compensatory mortality or reproduction processes that 
render such restoration ineffective or even counterproductive. Particularly in cases where breeding habitat is ultimately limiting, habitat protection would often seem the wisest choice for restoration. In addition, there are unforeseen but possible ecosystem changes that could result from the rapid addition of large quantities of predators. By preventing future declines in bird populations, the effect on their prey communities remains relatively unchanged. Many of these marine birds can exert a high level of control on prey communities (Hamilton 2000). Rapidly increasing current levels of predation through artificial breeding programs could inadvertently injure other consumers that feed on similar prey. For example, many fish and crab species prey on the same benthic invertebrates that loons and eiders prey upon (Hamilton 2000).

The decision to compensate for losses to a wide suite of marine birds by developing and implementing a restoration project for a single species, the common eider, raises several issues. First, such a choice has implications to the ecosystem in which these birds are a part. The injury clearly affected a diversity of species, which restoration will not necessarily enhance. The importance of biodiversity to the stability and resilience of communities has been demonstrated in several studies (Naeem et al. 1994, Tilman \& Downing 1994). Furthermore, preserving biodiversity is a major focus of conservation biology for multiple reasons, including ethics, aesthetics, and sustainability of ecosystem function (Wilson 1992). Consequently, one could challenge the decision to restore many with one. Such a choice is motivated in large measure by efficiency: development and implementation of many small restoration projects would multiply costs several fold and result in fewer birds produced per unit expense. Nevertheless, the question remains of whether the public trust resource is truly restored by ecologically unbalanced restoration and whether using lower costs to justify that action is defensible for agencies charged with protecting the public trust resources. Fortunately, in the case of selecting a habitat preservation option, it is clear that numerous species besides the targeted one will benefit.

Habitat protection, particularly of breeding and spawning grounds, represents an effective and ecologically responsible mechanism to restore natural population of marine species. For marine fishes and invertebrates, establishment of marine reserves as well as the protection and/or restoration of essential fish habitat can be viewed as adopting a similar philosophy. Recent studies have demonstrated the effectiveness of both strategies in restoring marine fish populations (Roberts et al. 2002, Peterson et al. 2003b, in this Theme Section). Our analyses here use a combination of syntheses of regional empirical studies and broader conceptual theory to make quantitative predictions of the net benefits of habitat protection/ restoration for 2 marine birds: loons and eiders. Such calculations can be viewed as explicit hypotheses for future studies and could be evaluated through rigorous 'follow-up' monitoring of restoration projects.

Acknowledgements. Funding for the preparation of this manuscript was provided by the National Oceanic and Atmospheric Administration (NOAA), Damage Assesement Center and the US Fish and Wildlife Service. The comments of C. H. Peterson, J. Burger, D. Esler, K. Carr and B. Allen improved this manuscript. D. Evers, C. Hebert and D. Kane guided and assisted the process.

\section{LITERATURE CITED}

Agler BA, Kendall SJ, Irons DB, Klosiewski SP (1999) Declines in marine bird populations in Prince William Sound, Alaska coincident with a climatic regime shift. Waterbirds 22:98-103

Belant JL, Anderson RK (1991) Common loon, Gavia immer, productivity on a northern Wisconsin impoundment. Can Field Nat 105:29-33

Bellrose FC (1976) Ducks, geese and swans of North America. Stackpole Books, Harrisburg, PA

Blumton AK, Owen RB Jr, Krohn WB (1988) Habitat suitability index models: American eider (breeding). US Fish and Wildlife Service Biological Report 82(10.149), Washington, DC

Boersma PD, Clark JA, Hillgarth N (2001) Seabird conservation. In: Schreiber EA, Burger J (eds) Biology of marine birds. CRC Press, Boca Raton, FL, p 559-580

Bordage D, Savard JL (1995) Black scoter (Melanitta nigra). In: Poole A, Gill F (eds) The birds of North America. The Academy of Natural Sciences, Philadelphia and The American Ornithologist's Union, Washington, DC, No. 177, p 1-20

Burger AE (1993) Mortality of seabirds assessed from beached-bird surveys in southern British Columbia. Can Field Nat 107:164-176

Burger J (1997) Oil spills. Rutgers University Press, New Brunswick, NJ

Burger J (2003) Personal watercraft and boats: coastal conflicts with common terns. Lake Reserv Res Manag 19: $26-34$

Burger J, Gochfeld M (2001) Effects of chemicals and pollution on seabirds. In: Schreiber EA, Burger J (eds) Biology of marine birds. CRC Press, Boca Raton, FL, p 495-526

Carney KM, Sydeman WJ (1999) A review of human disturbance effects on nesting colonial waterbirds. Waterbirds 22:68-79

Caron JA, Robinson WL (1994) Responses of breeding common loons to human activity in upper Michigan. Hydrobiol 280:431-438

Clapp RB, Banks RC, Morgan-Jacobs D, Hoffman WA (1982) Marine birds of the southeastern United States and Gulf of Mexico. Part I. Gaviiformes through Pelecaniformes. Report FWS/OBS-82/01, US Fish and Wildlife Service, Washington, DC

Coon N, Dieter MP (1981) Responses of adult mallard ducks to ingested south Louisiana crude oil. Environ Res 24: 309-314

Croskery PR (1991) Common loon, Gavia immer, nesting suc- 
cess and young survival in northwestern Ontario. Can Field Nat 105:45-58

Eadie JM, Mallory ML, Lumsdem HG (1995) Common goldeneye (Bucephala clangula). In: Poole A, Gill F (eds) The birds of North America. The Academy of Natural Sciences, Philadelphia and The American Ornithologist's Union, Washington, DC, No. 170, p 1-32

Esler D, Schwartz JA, Jarvis RL, Mulchay DM (2000) Winter survival of adult female harlequin ducks in relation to history of contamination by the 'Exxon Valdez' oil spill. J Wildl Manag 64:839-847

Evers DC (1993) Northern Great Lakes common loon monitoring program: 1993 Field Season Final Report. Whitefish Point Bird Observatory, Paradise, MI

Evers DC (2001) Common Loon population studies: continental mercury patterns and breeding territory philopatry. PhD dissertation, University of Minnesota, St. Paul

Fjeldsa J (1973) Territory and the regulation of population density and recruitment in the horned grebe Podiceps auritus arcticus Boje, 1822. Vidensk Medd Dan Nat.hist Foren 136:117-189

French DP, Reed M, Jayko K, Feng S and 16 others (1996) The CERCLA Type A Natural Resource Damage Assessment Model for Coastal and Marine Environments (SIMAP). Technical Documentation, Vol. I-Model Description. US Dept of Interior, Washington, DC

Fry DM, Swenson J, Addiego LA, Grau CR, Kang A (1986) Reduced reproduction in wedge-tailed shearwaters exposed to weathered Santa Barbara crude oil. Arch Environ Contam Toxicol 15:453-463

Gauthier G (1993) Bufflehead (Bucephala albeola). In: Poole A, Gill F (eds) The birds of North America. The Academy of Natural Sciences, Philadelphia and The American Ornithologist's Union, Washington, DC, No. 67, p 1-32

Gingras BA, Paszkowski CA (1999) Breeding patterns of common loons on lakes with three different fish assemblages in north-central Alberta. Can J Zool 77:600-609

Golet GH, Seiser PE, McGuire AD, Roby DD and 6 others (2002) Long-term direct and indirect effects of the 'Exxon Valdez' oil spill on pigeon guillemots in Prince William Sound, Alaska. Mar Ecol Prog Ser 241:287-304

Goudie RI, Robertson GJ, Reed A (2000) Common eider (Somateria mollissima). In: Poole A, Gill F (eds) The Birds of North America. The Academy of Natural Sciences, Philadelphia and The American Ornithologist's Union, Washington, DC, No. 546, p 1-32

Grau CR, Roudybush T, Dobbs J, Wathern J (1977) Altered yolk structure and reduced hatchability of eggs from birds fed singe doses of petroleum oils. Science 195:779-781

Hamilton DJ (2000) Direct and indirect effects of predation by common eiders and abiotic disturbance in an intertidal community. Ecol Monogr 70:21-43

Hlady DA, Burger AE (1993) Drift-block experiments to analyze the mortality of oiled seabirds off Vancouver Island, British Columbia. Mar Pollut Bull 26:495-501

Hoffman DJ (1990) Embryotoxicity and teratogenicity of environmental contaminants to bird eggs. Rev Environ Contam Toxicol 115:40-89

Irons DB, Kendall SJ, Erickson WP, McDonald LL, Lance BK (2000) Nine years after the 'Exxon Valdez' oil spill: effects on marine bird populations in Prince William Sound, Alaska. Condor 104:723-737

Johnsgard PA (1975) Waterfowl of North America. Indiana University Press, Bloomington

Editorial responsibility: Charles Peterson (Contributing Editor), Morehead City, North Carolina, USA
Johnsgard PA (1987) Diving birds of North America. University of Nebraska Press, Lincoln

Kilpi M, Lindstrom K (1997) Habitat-specific clutch size and cost of incubation in common eiders, Somateria mollissima. Oecologia 111:297-301

McIntyre JW (1988) The common loon: spirit of Northern Lakes. University of Minnesota Press, Minneapolis

McIntyre JW, Barr JF (1997) Common loon (Gavia immer). In: Poole A, Gill F (eds) The birds of North America. The Academy of Natural Sciences, Philadelphia and The American Ornithologist's Union, Washington, DC, No. 313, p 1-32

Montevecchi WA (2001) Interaction between fisheries and seabirds. In: Schreiber EA, Burger J (eds) Biology of marine birds. CRC Press, Boca Raton, FL, p 527-558

Naeem S, Thompson LJ, Lawlor SP, Lawton JH, Woodfin RM (1994) Declining biodiversity can alter the performance of ecosystems. Nature 368:734-737

NOAA (1999) Discounting and the treatment of uncertainty in natural resource damage assessment. Tech Paper 99-1, NOAA, Silver Spring, MD

Owen M, Black JM (1989) Barnacle goose. In: Newton I (ed) Lifetime reproduction in birds. Academic Press, San Diego, CA, p 349-362

Peterson CH (2001) The 'Exxon Valdez' oil spill in Alaska: acute, indirect and chronic effects on the ecosystem. Adv Mar Biol 39:1-103

Peterson CH, Kneib RT, Manen C-A (2003a) Scaling restoration actions in the marine environment to meet quantitative targets of enhanced ecosystem services. Mar Ecol Prog Ser 264:173-175 (in this Theme Section)

Peterson CH, Grabowski JH, Powers SP (2003b) Estimated enhancement of fish production resulting from restoring oyster reef habitat: quantitative valuation. Mar Ecol Prog Ser 264:249-264 (in this Theme Section)

Piatt JF, Lensink CJ (1989) 'Exxon Valdez' bird toll. Nature 342:865-866

Piper WH, Tischler KB, Klich M (2000) Territory acquisition in loons: the importance of the take-over. Anim Behav 59: 385-395

Piper WH, Meyer MW, Klich M, Tischler KB, Dolsen A (2002) Floating platforms increase reproductive success of common loons. Biol Conserv 104:199-203

Roberts CM, Bohnsack JA, Gell F, Hawkins JP, Goodridge R (2002) Effects of marine reserves on adjacent fisheries. Science 294:1920-1923

Taylor K, Vogel H (1998) Summary of loon restoration preservation committee research and managment activities for the 1997 field season. Loon Preservation Committee, Holderness, $\mathrm{NH}$

Taylor K, Vogel H (2000) New Hampshire Report. In: McIntyre JW, Evers DC (eds) Loons: old history and new findings. Symp Proc 1997 meeting, American Ornithologists' Union, N Am Loon Fund, Holderness, NH, p 110-113

Tilman D, Downing JA (1994) Biodiversity and stability in grasslands. Nature 367:363-365

Trivelpiece WR, Butler RG, Miller DS, Peakall DB (1984) Reduced survival of chicks of oil-dosed Leach's storm petrels. Condor 86:81-82

Wilson EO (1992) Diversity of life. Harvard University Press, Cambridge, MA

Wooller RD, Bradley JS, Skira IJ, Serventy DL (1989) Shorttailed shearwater. In: Newton I (ed) Lifetime reproduction in birds. Academic Press, San Diego, CA, p 405-418

Submitted: December 10, 2002; Accepted: October 27, 2003

Proofs received from author(s): December 4, 2003 